\title{
柱降伏を伴う梁降伏型多層骨組の損傷分布則 DAMAGE DISTRIBUTION LAW OF WEAK-BEAM TYPE MULTI-STORY FRAMES ACCOMPANIED BY YIELDING OF COLUMNS
}

\author{
小久保 彰*, 半貫敏夫**, 秋山 宏*** \\ Akira KOKUBO, Toshio HANNUKI and Hiroshi AKIYAMA
}

\begin{abstract}
It is important to predict the distribution of damage for the seismic design purpose. In this paper, in order to evaluate the damage distribution of weak-beam type multi-story frames influenced by the yield of column bases, an elasto-plastic response analysis on fishbone-shaped frames was carried out. The damage distribution is influenced by the distribution of the strength and the stiffness ratios of beam to column. From results of analysis, a basic rule which governs the damage distribution of realistic weak-beam type multi-story frames was proposed in a simple formula.
\end{abstract}

\section{Keywords : Weak-Beam Type Multi-Story frames, Fishbone-Shaped Frame Model, Damage Distribution, Stiffness Ratio of Beam and Column, Damage concentration 梁降伏型多層骨組，魚骨モデル，損傷分布，梁柱剛性比，損傷集中}

\section{1. 序}

多層骨組の耐震設計では、地震により構造物に投入されるエネル ギーの大部分が構造物の累積塑性ひずみエネルギー(損傷)として吸 収されることから、構造物各部へエネルギーがどのように配分され るのか、損傷分布についての考慮が重要となる。多層骨組の耐震性 に優れる構造形態として梁降伏型骨組が知られている。せん断型骨 組を対象とした、梁降伏型骨組の損傷分布の基本則が文献 1),2)にて 提唱されている。著者らは文献 2) と同様の手法を部材レベルの変形 を評価できる魚骨モデルに適用し、各層の柱は弾性に留まり、梁の みが塑性化する梁降伏型骨組の損傷分布則を部材レベルの予測式と して示した ${ }^{3)}$ 。実際の構造物では、梁降伏型は必ずしも各層の梁の みが塑性化するものではなく、第 1 層柱脚や最上層柱頭の塑性化を 伴うものがある。梁降伏型崩壊機構の形成には、柱と梁の耐力比お よび岡性比が影響を与えることが明らかにされている 4$), 5), 6$ )など。本 論文は各層の梁のみが塑性化する梁降伏型骨組を基準骨組とし、第 1 層に着目した応答解析結果から、基準骨組との比較により梁降伏 型の崩壊機構が柱降伏を伴う場合の損傷分布特性を検証し、文献 3) で提案した損傷分布則が、最下部柱の降伏を伴う現実的な梁降伏型 多層骨組に適用できることを示す。

\section{2. 梁降伏型多層骨組における柱脚降伏}

\section{1 梁降伏型多層骨組の崩壊機構}

終局状態にある梁降伏型多層骨組が形成する崩壊機構として、2 種 類のメカニズムを考える。一つは各層の梁のみが塑性化する梁降伏型 崩壊機構、もう一つは各層梁および最下部柱が塑性化する柱降伏を伴 う梁降伏型崩壊機構である。それぞれの崩壊機構を、鋼構造多層多ス パン骨組を代表する梁降伏型魚骨モデルを用いて図 1a)、b)に示寸。 多層骨組が梁降伏型の崩壊機構を形成するには、柱の降伏耐力が梁の 降伏耐力を上回る必要があり、梁降伏型成立の条件として、各層上部 梁耐力の 1.3 倍以上の柱耐力が必要であることが示されている ${ }^{2)}$ 。し かし、最下部に関しては節点での応力の釣合いから、柱の降伏耐力が 梁の降伏耐力を上回れば a)の機構を形成し、下回れば b)の機構を形 成する。

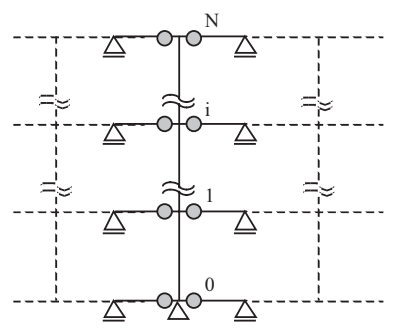

a ) 梁のみが降伏する機構

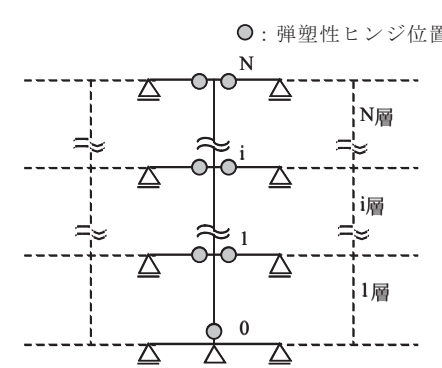

b ) 柱降伏を伴う機構
図 1 梁降伏型多層骨組モデル

\section{* 日本大学理工学部建築学科 助手·工修}

** 日本大学理工学部建築学科 教授. 工博

*** 日本大学総合科学研究所 教授. 工博
Research Assoc., Dept. of Architecture, Collage of Science and Technology, Nihon Univ., M. Eng.

Prof., Dept. of Architecture, Collage of Science and Technology, Nihon Univ., Dr. Eng.

Prof., University Research Center, Nihon Univ., Dr. Eng. 


\section{2 基準骨組の設定}

図 1a)に示す崩壊機構を形成する骨組において、各層の階高が全 て等しく、各層のせん断強度分布が最適降伏せん断力係数分布と等 しい場合を、骨組の基準状態(基準骨組)として設定する。基準骨組 は塑性化する全ての部材の累積塑性変形倍率が等しくなるものとす る。基準骨組の柱の反曲点を階高の中央にあると仮定すると、骨組 の降伏せん断力分布は最適降伏せん断力係数分布 $\bar{\alpha}_{\mathrm{i}}$ 用いて、次式 で表される。

$$
\begin{aligned}
& \overline{Q_{Y i}}=\frac{Q_{Y i}}{Q_{Y 1}}= \frac{\sum_{j=i}^{N} m_{j} \cdot \alpha_{i} \cdot g}{M \cdot \alpha_{1} \cdot g}=\left(\frac{\sum_{j=i}^{N} m_{j}}{M}\right) \overline{\alpha_{i}} \\
& こ こ て ゙ 、 m_{j}: \mathrm{j} \text { 層上部の質点の質量 } \\
& g \quad: \quad \text { 重力加速度 } \\
& \bar{\alpha}_{i}=\alpha_{i} / \alpha_{1} \\
& \alpha_{i}: \mathrm{i} \text { 層の降伏せん断力係数 } \\
& \alpha_{1}: \text { 第 } 1 \text { 層の降伏せん断力係数 } \\
& M=\sum_{j=1}^{N} m_{j}: \text { 総質量 }
\end{aligned}
$$

図 2 に示寸節点の釣合いから梁材端のモーメント分布を求め、これ を梁材端の降伏モーメント分布とし、次式で示す。

最上層上部

$$
\begin{aligned}
& \overline{{ }_{b} M_{Y N}}=\frac{{ }_{b} M_{Y N}}{{ }_{b} M_{Y 0}}=\frac{Q_{Y N} \cdot H / 2}{Q_{Y 1} \cdot H / 2}=\overline{Q_{Y N}} \\
& \frac{\mathrm{i} \text { 層上部 }}{{ }_{b} M_{Y i}}=\frac{{ }_{b} M_{Y i}}{{ }_{b} M_{Y 0}}=\frac{\left(Q_{Y i+1}+Q_{Y i}\right) \cdot H / 2}{Q_{Y 1} \cdot H / 2} \fallingdotseq \frac{2 Q_{Y i}}{Q_{Y 1}}=2 \overline{Q_{Y i}} \\
& \frac{\text { 最下部 }}{{ }_{b} M_{Y 0}}=1.0
\end{aligned}
$$

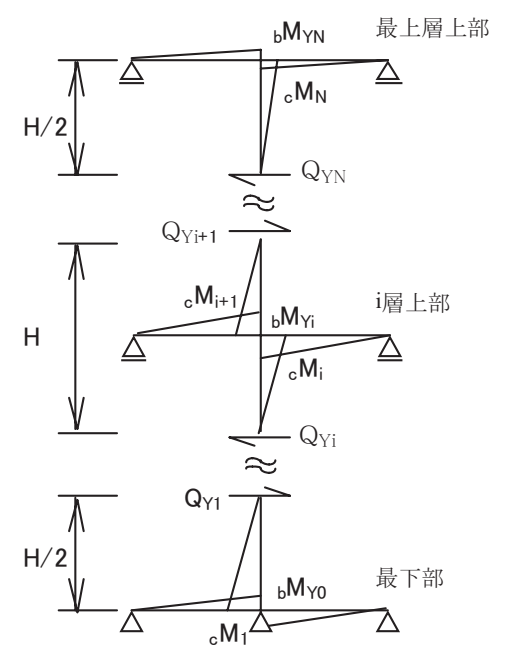

図 2 節点応力の釣合い

(1)式の最適降伏せん断力係数分布 $\bar{\alpha}_{\mathrm{i}}$ は、連続関数として次式で与え られる2)。

$$
\begin{aligned}
& \overline{\alpha_{i}}=f\left(\frac{i-1}{N}\right) \\
& \text { ここで、 } f(x)=1+1.5927 x-11.852 x^{2}+42.583 x^{3}-59.48 x^{4}+30.16 x^{5}
\end{aligned}
$$

\section{3 解析モデル}

応答解析に用いるモデルは 1 自由度無減衰多質点弾塑性系で、骨 組モデルは、図 1 に示した鋼構造多層多スパン骨組を代表する部材 レベルの梁降伏型魚骨モデルである。層数は 5,10,15の 3 種類で、 各層の階高および質量分布は全て等しいものとした。梁降伏型骨組 のエネルギー吸収は、完全弾塑性型の復元力特性を持つ梁または柱 部材端部の塑性化によるものである。図中の番号は節点番号を示し ており、最下部節点の番号は 0 である。各質点系の弾性 1 次固有周 期は次式による值とした ${ }^{7)}$ 。

$$
\left.\begin{array}{ll}
T=0.2 N & (N \leqq 5) \\
T=0.55+0.085 N & (N>6)
\end{array}\right\}
$$

上式より $5,10,15$ 質点系の弾性 1 次固有周期をそれぞれ $\mathrm{T}=1.0 \mathrm{~s}$, $1.4 \mathrm{~s}, 1.8 \mathrm{~s}$ とした。入力地震波は El Centro-NS、解析パラメーターは 梁部材の剛度 ${ }_{b} k\left(={ }_{b} M_{Y} / b_{b} \theta_{Y} 、{ }_{b} M_{Y}\right.$ : 梁の降伏モーメント, ${ }_{b} \theta_{\mathrm{Y}}$ : 梁の降 伏回転角 $)$ に対する柱部材の剛度 ${ }_{\mathrm{c}} \mathrm{k}\left(=_{\mathrm{c}} \mathrm{M}_{\mathrm{Y}} / \mathrm{c}_{\mathrm{c}} \theta_{\mathrm{Y}} 、{ }_{\mathrm{c}} \mathrm{M}_{\mathrm{Y}}\right.$ : 柱の降伏モー メント, ${ }_{\mathrm{c}} \theta_{\mathrm{Y}}$ : 柱の降伏回転角)の比を表す梁柱剛性比 $\mathrm{k}_{\mathrm{bc}}\left(={ }_{\mathrm{b}} \mathrm{k} / \mathrm{c} \mathrm{k}\right)$ で、 各層一定である。基準骨組として設定するモデルは、図 1a)に示し た各層上部梁端部および基礎梁端部が塑性化する梁降伏型機構を形 成し、梁材端の累積塑性変形倍率 ${ }_{\mathrm{b}} \eta_{\mathrm{i}}$ を各部材一定とする強度分布 を持つものとする。基準骨組の強度分布は 5、10、15 層骨組につい て、 $\mathrm{b} \eta_{\mathrm{i}}$ が 10.0 で各部材一定となるように、高さ方向の強度分布を 試行錯誤的に変化させる応答解析を繰り返し実行し、その結果から 梁材端の降伏モーメント分布を図 3 のように設定した。図の縦軸は 各節点を相対高さとして表した(i-1)/N である。ただし、 $\overline{\mathrm{b}} \overline{\mathrm{M}} \mathrm{Y} 0$ の縦軸 の位置は 0 とする。横軸は基準骨組の梁材端降伏モーメント分布で ある。図中の点線と実線は、(1)、(2)、(3)式より求めた基準骨組の 梁材端降伏モーメント分布で、点線が最下部および最上部梁、実線 が $\mathrm{i}$ 層上部梁を示している。 $\mathrm{k}_{\mathrm{bc}}$ は 0.5 及び 1.0 である。図から基準 骨組の梁材端降伏モーメント分布は、層数や梁柱剛性比に影響を受 けない一定の分布であることがわかる。

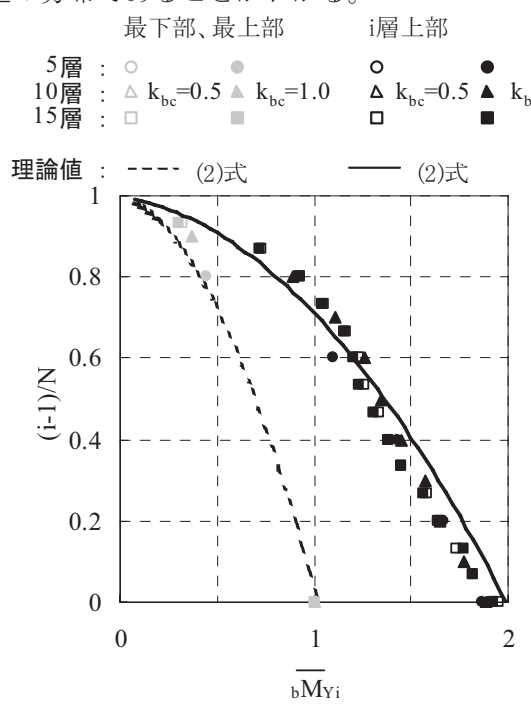

図 3 解析モデルの梁材端降伏モーメント分布 


\section{3. 最下部節点部材の損傷}

\section{1 最下部梁強度と損傷の関係}

実構造物では基礎梁の耐力が、第 1 層柱脚の耐力を上回る場合が 考えられる。図 $1 b$ )に示した最下部柱の降伏を伴う梁降伏型の崩壊 機構は、図 1a)の骨組の最下部において、梁の降伏耐力が柱の降伏 耐力を上回ることにより実現する。すなわち、骨組最下部の節点に 着目し、図 1a)に示寸基準状態にある骨組に対して、最下部梁の強 度のみを増加した場合の最下部節点部材の損傷を応答解析により求 める。基準骨組の第 1 層柱脚を除く各層の柱はまったく降伏しない ものとする。

\section{1.1 最下部梁強度の増加と損傷}

基準骨組の最下部梁強度を変化させたときの、最下部節点部材の 損傷を、梁と柱の耐力と損傷の関係として図 4 に示す。図の縦軸は 最下部節点部材のエネルギー集中比、横軸は最下部節点の柱降伏モ ーメント ${ }_{\mathrm{c}} \mathrm{M}_{\mathrm{Y} 1}$ に対する梁降伏モーメント ${ }_{\mathrm{b}} \mathrm{M}_{\mathrm{Y} 0}$ の比である梁柱耐力 比 ${ }_{\mathrm{b}} \mathrm{M}_{\mathrm{Y} 0} /{ }_{\mathrm{c}} \mathrm{M}_{\mathrm{Y} 1}$ である。エネルギー集中比は最下部梁の降伏耐力が最 適状態である場合のエネルギー吸収量 ${ }_{0 b} \mathrm{~W}_{\mathrm{P} 0}$ に対する、最適状態か らはずれる場合の最下部節点におけるエネルギー吸収量 $\mathrm{W}_{\mathrm{P} 0}$ の比 $\mathrm{W}_{\mathrm{P} 0} /{ }_{0 b} \mathrm{~W}_{\mathrm{P} 0}$ として得られる。図から梁の耐力上昇にともない、梁損傷 の減少が見られ、柱耐力が梁耐力と等しくなる ${ }_{\mathrm{b}} \mathrm{M}_{\mathrm{Y} 0} /{ }_{\mathrm{C}} \mathrm{M}_{\mathrm{Y} 1}=1$ を境に 降伏部位が梁から柱へと移行し、それ以降は柱脚が降伏寸る機構を 形成し、梁耐力の上昇とは無関係に柱脚の損傷が一定となることが わかる。この結果から基準骨組の最下部梁強度の変化が、最下部節 点の降伏ヒンジを形成する位置に影響を与える要因と言える。

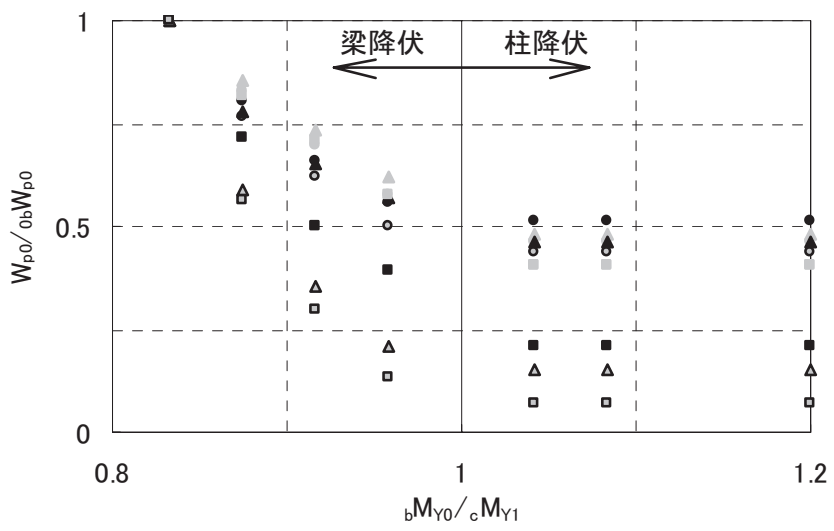

図 4 最下部梁の強度変化と損傷の関係

\section{1 .2 梁強度変化時の損傷予測}

著者らは文献 3)において、梁降伏型骨組の損傷分布則を次式で提 案した。

$$
\begin{aligned}
& \frac{{ }_{b} W_{P_{i}}}{W_{P}}=\frac{S_{i}{ }^{\prime} p_{i}{ }^{\prime n}}{\sum_{j=0}^{N} S_{j}{ }^{\prime} p_{j}{ }^{\prime}{ }^{n}} \\
& \text { ここで、 } \left.s_{i}{ }^{\prime}=\left(\sum_{j=i}^{N} m_{j} / M\right)^{2} \alpha_{i}{ }^{2}{ }_{b} k_{0} /{ }_{b} k_{i}\right) \\
& \begin{array}{l}
m_{j}: \mathrm{j} \text { 層上部の質点の質量, } M=\sum_{j=1}^{N} m_{j} \text { : 総質量 } \\
\bar{\alpha}_{i}{ }^{\prime}=\alpha_{i}{ }^{\prime} / \alpha 0^{\prime}
\end{array} \\
& \alpha_{i}{ }^{\prime} \text { : i 層上部梁材端降伏モーメント係数 } \\
& \alpha_{0} \text { '：最下部梁材端降伏モーメント係数 } \\
& { }_{b} k_{i}: \text { 梁の曲げ剛性 } \\
& p_{j}{ }^{\prime}=\frac{\alpha_{j}{ }^{\prime}}{\alpha_{0}{ }^{\prime} \overline{\alpha_{j}{ }^{\prime}}} \\
& p_{j}{ }^{\prime} \text { : 梁部材端部降伏応力の最適值からの偏差 } \\
& n: \text { 損傷集中指数 }
\end{aligned}
$$

基準状態にある骨組の最下部梁の強度増加による部材損傷の変化を、 (5)式により予測する。部材損傷の変化は最下部梁降伏耐力が最適状 態である場合に対する、最適状態より増加する場合の最下部節点部 材損傷の比 $\mathrm{W}_{\mathrm{P} 0} / \mathrm{ob}_{\mathrm{b}} \mathrm{W}_{\mathrm{P} 0}$ として求める。骨組の降伏耐力が最適状態で ある場合、最下部節点では梁に降伏ヒンジが形成され、(5)式におけ る $\mathrm{p}_{\mathrm{j}}$ 'が 1.0 となり、nの值にかかわらず最下部節点の損傷は次式と なる。

$$
\frac{{ }_{0 b} W_{P 0}}{W_{P}}=\frac{s_{0}{ }^{\prime}}{\sum_{i=0}^{N} s_{i}{ }^{\prime}}
$$

最下部梁部材の強度増加時の損傷は、最適状態における降伏耐力を $\mathrm{p}_{\mathrm{d}}\left(\mathrm{p}_{\mathrm{d}}>1.0\right)$ 倍したときの最下部節点部材の損傷として次式で表す。

$$
\frac{W_{P 0}}{W_{P}}=\frac{S_{0}{ }^{\prime} p_{0}{ }^{\prime n} p_{d}{ }^{n}}{S_{0}{ }^{\prime} p_{0}{ }^{\prime n} p_{d}{ }^{n}+\sum_{i \neq 0}^{N} S_{i}{ }^{\prime} p_{i}{ }^{\prime n}}
$$

基準状態 $\left(\mathrm{p}_{\mathrm{j}}=1.0, \mathrm{n}=0\right)$ にある骨組を初期状態に設定し、最下部梁部 材の強度増加を $\mathrm{p}_{\mathrm{d}}$ として与えた場合の解析結果を図 5 に示す。損傷 集中指数 $\mathrm{n}$ は $6 、 \mathrm{p}_{\mathrm{j}}{ }^{\prime}$ は 1.0 を用いる。最下部節点における柱の降伏 耐力 $\mathrm{c}_{\mathrm{M}} \mathrm{Y}_{1}$ は、 $\mathrm{p}_{\mathrm{d}}=1.2$ で梁の降伏耐力 ${ }_{\mathrm{b}} \mathrm{MY} 0$ と釣合うように設定した。 図中に実線で(5)式から求められた予測值を示している。図から(5) 式による予測值は、最下部節点部材の $\mathrm{p}_{\mathrm{d}}$ の増加により変化する損傷 の応答值と同様の傾向を示し、梁の降伏耐力が柱の降伏耐力を上回 ることにより生じる降伏部位の移動にも対応していることがわかる。 


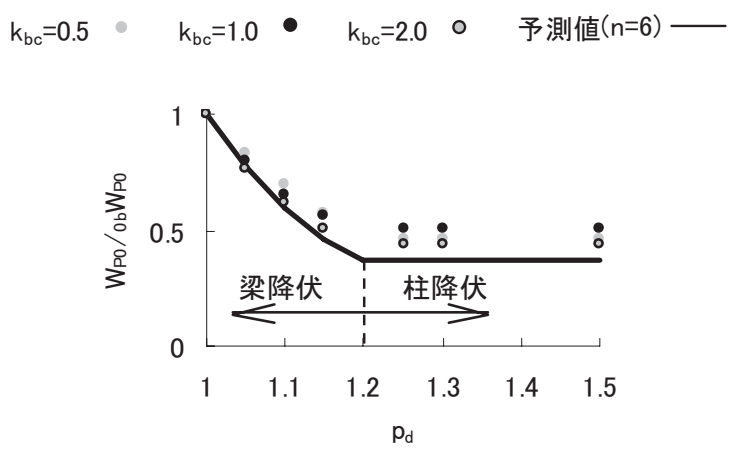

a) 5 層

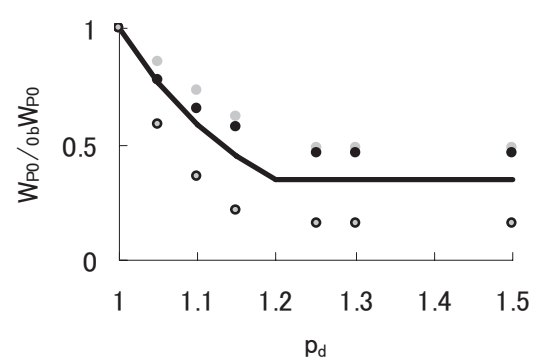

b) 10 層

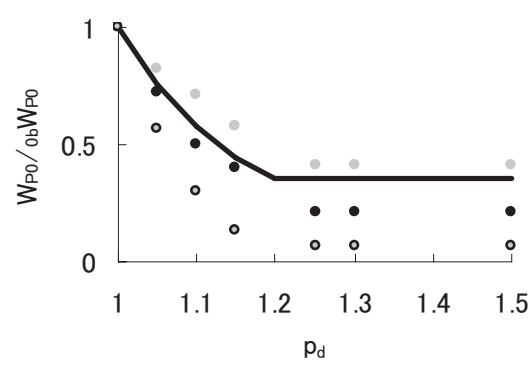

c) 15 層

図 5 損傷予測

\section{2 最下部梁剛性と損傷の関係}

図 1 において最下層柱の下部にはピン支点 $(\triangle)$ が設けられている。 これは基準骨組を適切に表現するために設けたものである。現実に はこのピン支点を実現することは大きな柱軸力の存在により困難で あり、柱下端部は固定支持に近くなる。この条件を図 1 のモデルを 用いて実現するには、最下層梁の剛性、強度を高める必要が生ずる。 このような観点から、以下に最下層梁の剛性、強度を高めた場合の 損傷分布を評価する。

\section{2.1 最下部梁剛性の増加と損傷集中}

第1層柱脚の固定度が高く、梁柱剛性比の小さい多層骨組の場合、 第 1 層への損傷集中率が高くなり、柱脚の固定度を低くすることで その損傷集中を緩和できることが山田、呉らにより報告されている 6),8)。基準骨組の最下部梁の強度は変化させず、最下部梁剛性のみを 増大させた場合の 5 層骨組における応答を、全損傷に占める各部材 の損傷として各節点ごとに、 $\mathrm{k}_{\mathrm{bc}}=0.1,0.5,1.0,2.0$ の 4 種類について図 6 に示す。図には基準骨組 $\left({ }_{\mathrm{b}} \mathrm{k}_{0}={ }_{0 \mathrm{~b}} \mathrm{k}_{0} 、{ }_{\mathrm{b}} \mathrm{k}_{0}\right.$ は解析モデル、 ${ }_{0 \mathrm{~b}} \mathrm{k}_{0}$ は基準骨組 の最下部梁剛性を示す)、最下部梁剛性を基準骨組の 3 倍とした骨組 $\left.{ }_{(b} \mathrm{k}_{0}=3{ }_{0 b} \mathrm{k}_{0}\right) 、 100$ 倍とした骨組 $\left({ }_{b} \mathrm{k}_{0}=100_{0 b} \mathrm{k}_{0}\right)$ の 3 種類について損傷分布
を示した。図からいずれの解析結果も、剛性を増大させた最下部梁 一損傷が集中し、他の部材の損傷が減少する傾向が見られ、この傾 向は梁柱剛性比 $\mathrm{k}_{\mathrm{bc}}$ が小さいほど顕著である。このときの最下部節点 に着目すると、損傷は剛性の増加した梁のみで増大し、柱での降伏 は見られなかった。このことから、最下部梁剛性の増加は、第 1 層 への損傷集中を生じさせるが、最下部節点の降伏ヒンジを梁から柱 一移行させるものではなかった。

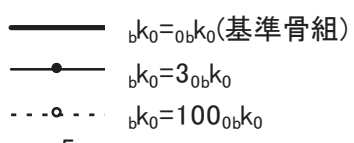

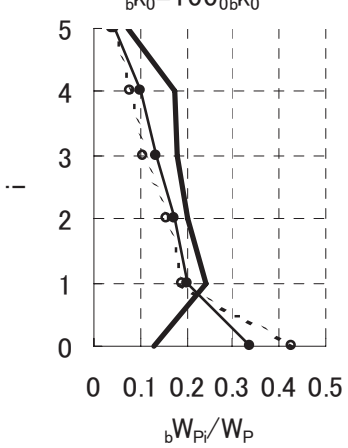

a) $\mathrm{k}_{\mathrm{bc}}=0.1$

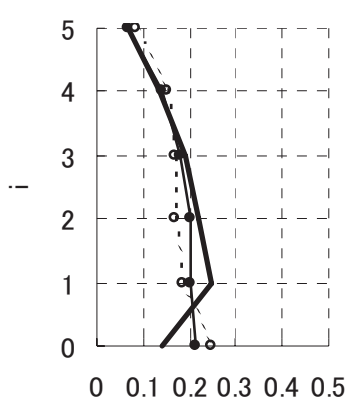

${ }_{b} \mathrm{~W}_{\mathrm{Pi}} / \mathrm{W}_{\mathrm{P}}$

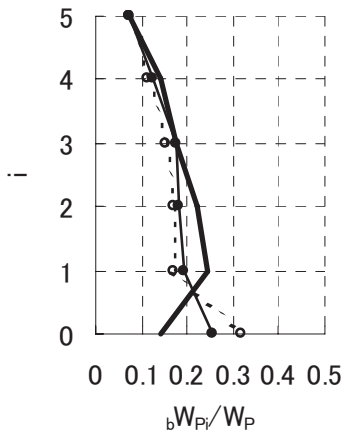

b) $\mathrm{k}_{\mathrm{bc}}=0.5$ c) $\mathrm{k}_{\mathrm{bc}}=1.0$

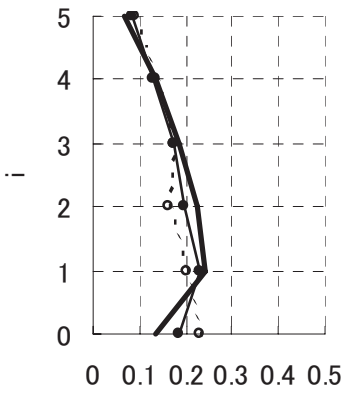

${ }_{b} \mathrm{~W}_{\mathrm{Pi}} / \mathrm{W}_{\mathrm{P}}$ d) $\mathrm{k}_{\mathrm{bc}}=2.0$

図 6 最下部梁剛性の増加と損傷分布

\section{2.2 損傷集中特性}

最下部梁の損傷は、梁部材端部のエネルギー吸収能力 て、次式で表される。

$$
\begin{aligned}
&{ }_{b} W_{P 0}={ }_{b} M_{Y 0}{ }_{b} \theta_{P 0} \\
& \text { ここで、 }{ }_{b} \theta_{P 0} \quad: \quad \text { 累積塑性変形角 }
\end{aligned}
$$

最下部梁の強度は変えずに、剛性のみの増加による損傷の増大は、 上式における ${ }_{\mathrm{b}} \theta_{\mathrm{P} 0}$ が 増大したことになる。そこで本解析モデルに おける最下部梁剛性と累積塑性変形角の関係を、応答解析の結果か ら図 7 に示す。図の横軸は最下部梁における基準骨組からの剛性の 変化率 $\mathrm{b}_{\mathrm{b}} \mathrm{K}_{0} \mathrm{ob}_{\mathrm{b}} \mathrm{k}_{0}$ 、縦軸は最下部梁における基準骨組からの累積塑性変 形角の変化率。 $\theta_{0} / 0_{b} \theta_{0}$ である。図から累積塑性変形角は梁剛性の増 加とともに増大寸る傾向が見られ、 $\mathrm{k}_{\mathrm{bc}}$ が小さいほどその比率も大き い。この傾向は最下部梁剛性が基準骨組の 3 倍程度までは強く見ら れるが、3 倍を超えるとその比率は低下寸る傾向にある。解析結果 より、最下部梁剛性と累積塑性変形角の関係をおおむね次式で近似 し、評価する。 
1) $\mathrm{b}_{\mathrm{b}} / \mathrm{ob}_{\mathrm{b}} \mathrm{k}_{0} \leqq 3$ の場合

$$
\frac{{ }_{b} \theta_{P 0}}{{ }_{0 b} \theta_{P 0}}=1.2 \frac{{ }_{b} k_{0}}{{ }_{0 b} k_{0}}
$$

2) ${ }_{b} \mathrm{k}_{0} /{ }_{0 b} \mathrm{k}_{0}>3$ の場合

$$
\begin{aligned}
\frac{{ }_{b} \theta_{P 0}}{{ }_{0 b} \theta_{P 0}} & =3.6+\frac{1}{100} \cdot \frac{{ }_{b} k_{0}}{{ }_{0 b} k_{0}} \\
\text { ここで、 }{ }_{0 b} \theta_{P 0} & : \text { 基準骨組の累積塑性変形角 } \\
{ }_{0 b} k_{0} \quad: & \text { 基準骨組の梁剛性 }
\end{aligned}
$$

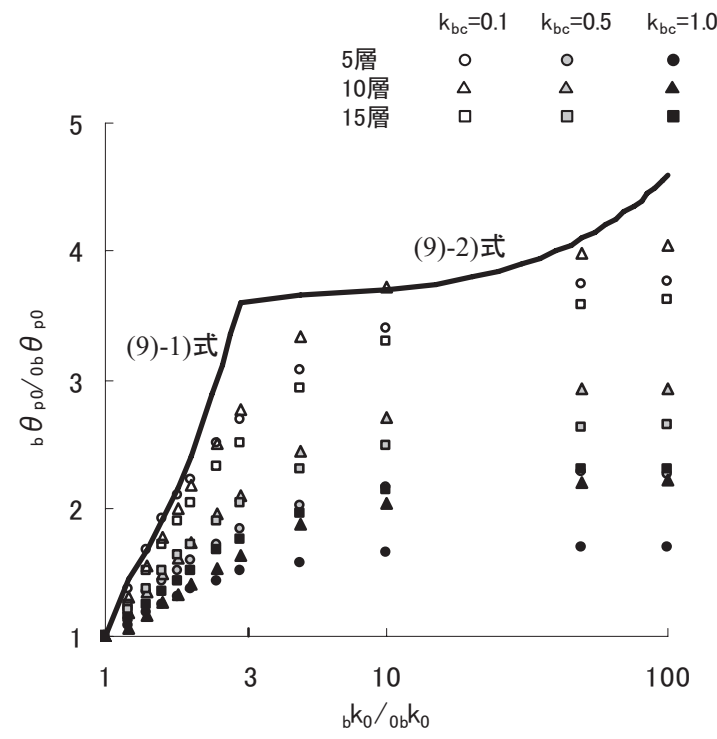

図 7 最下部梁剛性と累積塑性変形角の関係
2) $\delta_{\mathrm{g}} / \mathrm{c} \delta_{\mathrm{y}}>1$ の場合

$$
p_{1}=\frac{{ }_{g} M_{P}}{{ }_{c} M_{P}}\left(1.6-0.2 \cdot \frac{{ }_{g} M_{P}}{{ }_{c} M_{P}} \cdot \frac{k_{c}}{k_{g}}\right)
$$

${ }_{g} M_{P}:$ 梁の全塑性モーメント

${ }_{c} M_{P}:$ 柱の全塑性モーメント

$k_{g}:$ 梁の剛性

$k_{c}:$ 柱の剛性

g $\delta_{\mathrm{y}}={ }_{g} M_{P} / k_{g}$

${ }_{\mathrm{c}} \delta_{\mathrm{y}}={ }_{c} M_{P} / k_{c}$

本論では梁剛性の増加による損傷集中を、基準骨組の損傷に直接的 に、図 7 に示す結果から得られた(9)式を考慮し、次式で評価する。

1) ${ }_{\mathrm{b}} \mathrm{k}_{0} / \mathrm{ob}_{\mathrm{b}} \mathrm{k}_{0} \leqq 3$ の場合

$$
{ }_{b} W_{P 0}={ }_{b} M_{Y 0}{ }_{0 b} \theta_{P 0} \cdot \frac{{ }_{b} \theta_{P 0}}{{ }_{0 b} \theta_{P 0}}={ }_{b} M_{Y 0}{ }_{0 b} \theta_{P 0} \cdot 1.2 \frac{{ }_{b} k_{0}}{{ }_{0 b} k_{0}}
$$

2) ${ }_{\mathrm{b}} \mathrm{k}_{0} /{ }_{0 \mathrm{~b}} \mathrm{k}_{0}>3$ の場合

$$
{ }_{b} W_{P 0}={ }_{b} M_{Y 0}{ }_{0 b} \theta_{P 0} \cdot\left(3.6+\frac{1}{100} \cdot \frac{{ }_{b} k_{0}}{{ }_{0 b} k_{0}}\right)
$$

最下部梁剛性の増加による最下部梁損傷の変化を、(5)、(11)式によ り予測する。基準骨組における、最下部梁の剛性を 100 倍 $\left(\mathrm{b}_{0}=100_{0 \mathrm{~b}} \mathrm{k}_{0}\right)$ とした梁柱剛性比 $\mathrm{k}_{\mathrm{bc}}=0.1$ の骨組の、損傷予測值と解析 值との比較を各節点ごとに図 8 に示す。図中の $(10)$ 式から求められ る 0 節点の予測值は、損傷集中指数 $n=3$ を用いて、第 1 層の損傷と して得られた予測值を、比較のために $1 / 2$ 倍したものである。図か ら(5)、（11)式による予測值は解析值の傾向とほぼ一致することが確 認でき、文献 6)で提案された(10)式による予測值同様、梁柱剛性比 の変化による損傷集中を評価できることがわかる。

\section{解析値}

\section{2.3 梁剛性変化時の損傷予測}

山田、吳らは文献 6)において、梁と柱の耐力比、剛性比の影響で 生じる第 1 層への損傷集中を、次式に示寸損傷分布則における、第 1 層の強度分布の最適值からの偏差を示寸 $\mathrm{p}_{1}$ に、梁柱耐力比、剛性 比の影響を考慮することで評価している。

$$
\begin{gathered}
\frac{W_{P 1}}{W_{P}}=\frac{Q_{1} p_{1}^{-n}}{\sum_{j=1}^{N} Q_{j} p_{j}^{-n}} \\
\text { ここで、 } Q_{j}=\left(\sum_{j=1}^{N} m_{j}\right) \alpha_{j} / M \\
p_{j}: \text { 降伏耐力の最適值からの偏差 } \\
n: \text { 損傷集中指数 } \\
\left.p_{1}: 1\right)_{\mathrm{g} \delta} \delta_{\mathrm{y}} / \mathrm{c} \delta_{\mathrm{y}} \leqq 1 \text { の場合 } \\
\quad p_{1}=\frac{{ }_{g} M_{P}}{{ }_{c} M_{P}}\left(2.5-1.1 \cdot \frac{{ }_{g} M_{P}}{{ }_{c} M_{P}} \cdot \frac{k_{c}}{k_{g}}\right)
\end{gathered}
$$

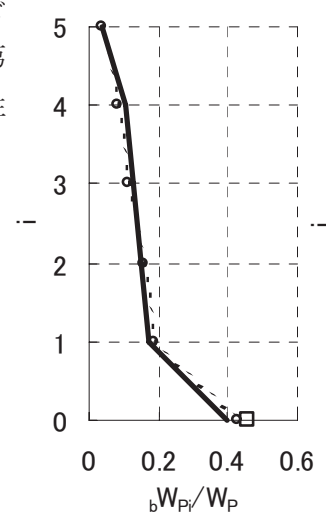

a) 5 層

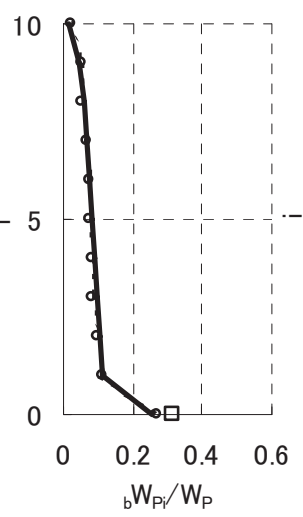

b) 10 層

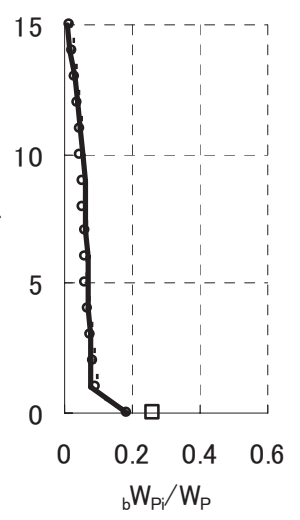

c) 15 層
図 8 損傷分布予測 


\section{3 最下部梁強度、剛性の変化と損傷}

最下部梁の強度と剛性が同時に変化する場合の最下部節点におけ る損傷を、 $\mathrm{n}=2,6$ を用いた(5)、(11)式により予測し、3.1.2 梁強 度変化時の損傷予測と同様の解析を行った結果との比較として図 9 に示す。最下部梁剛性は基準骨組の 100 倍( $\left.\mathrm{b}_{\mathrm{b}}=100_{0 \mathrm{~b}} \mathrm{k}_{0}\right)$ である。図か ら、骨組の応答は $\mathrm{k}_{\mathrm{bc}}$ が小さいほど損傷は増大し、いずれの骨組も最 下部梁強度の増加により損傷は減少する傾向にある。また、実構造 物で一般的だと考えられる $\mathrm{k}_{\mathrm{bc}} \geqq 0.3$ の範囲にある骨組では、著者ら が文献 3)にて示した、梁降伏型骨組における損傷集中指数 $\mathrm{n}=6$ を用 いた予測值は、 $\mathrm{k}_{\mathrm{bc}}$ の大きさにより若干のばらつきはあるものの、解 析值とほぼ同様の傾向を示しており、基準骨組における基礎梁の剛 性増大による損傷の集中、強度増大による損傷の緩和、および降伏 部位の梁端部から柱脚への変化を評価し得るものと言える。ただし、 $\mathrm{k}_{\mathrm{bc}}=0.1$ のように柱剛性に比べて梁剛性が極端に小さい場合、他の骨 組に比べ損傷の集中率が大きく、強度増加による損傷の減少率が小 さい傾向が見られ、 $\mathrm{n}$ を2程度とすることができる。

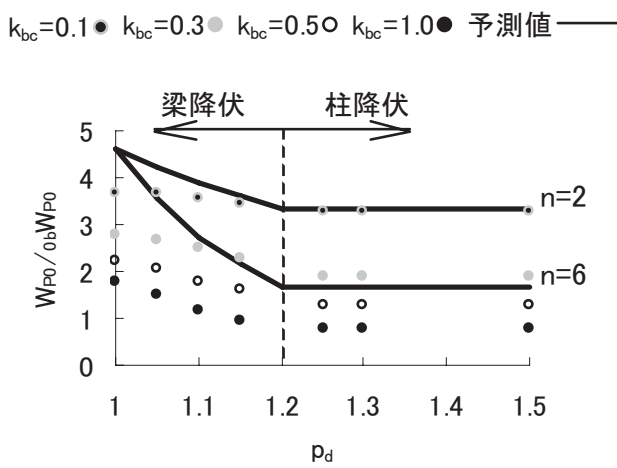

a) 5 層

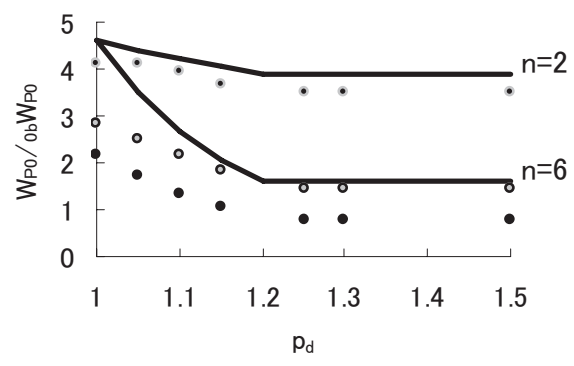

b) 10 層

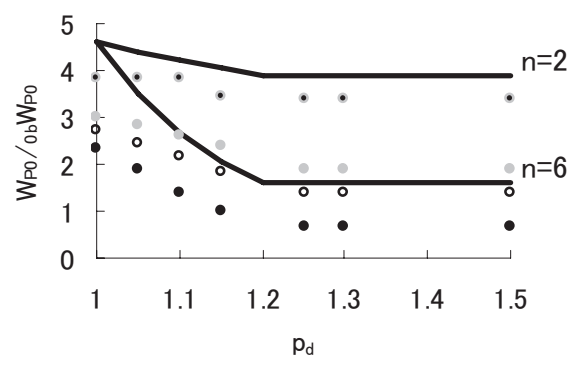

c) 15 層
5. まとめ

柱の塑性化を伴う梁降伏型多層骨組について、梁のみが塑性化す る骨組を基準とする第 1 層柱脚に着目した応答解析を行い、柱が塑 性化する条件を検証した。また著者らが文献 3)で提案した梁降伏型 多層骨組の損傷分布則を適用し、部材の損傷分布特性を示した。

1）梁降伏型骨組を実現するための柱が降伏しない条件として、柱 耐力が梁耐力の 1.3 倍以上必要であることが知られているが、 各層の梁のみが塑性化する梁降伏型基準骨組の最下部では、梁 耐力が柱耐力を上回ることにより、柱の塑性化を伴う降伏機構 を形成することを応答解析により示した。また文献 3)で提案し た梁降伏多層骨組の損傷分布則が、最下部梁耐力増加時の損傷、 及び降伏部位の予測に適用できることを示した。

2）梁柱剛性比の小さい梁降伏型多層骨組は、最下部に損傷が集中 しやすく、最下部梁剛性が高い程、その傾向が大きくなること を、部材レベルで確認した。このことから、梁降伏型骨組の実 現のため、柱を過度に大きくすることは、第 1 層への損傷集中 を招く原因となり得る。

3）梁柱剛性比及び最下部梁剛性の影響により生じる損傷集中評 価において、(5)式に最下部梁剛性と累積塑性変形角の関係を考 慮し、(11)式を得た。著者らが文献 3)で提案した、梁降伏型骨 組の現実的な損傷集中指数 $\mathrm{n}=6$ を用いた(5)式は、(11)式を考慮 することにより、基礎梁の剛性増大による損傷の集中を評価す ることが可能であり、応答解析結果との比較からその有効性を 示した。ただし、梁柱剛性比が極端に小さい $\mathrm{k}_{\mathrm{bc}}=0.1$ のような 骨組では、 $\mathrm{n}=2$ 程度とすることができる。

\section{参考文献}

1）加藤勉,秋山宏：地震時における鋼構造せん断型多層骨組の損傷分布則, 日本建築学会論文報告集 第 270 号, pp.61 68, 1978.8 .

2）秋山宏：梁降伏型鋼構造多層剛接骨組の $D_{S}$ 值，日本建築学会論文報告集 第 332 号, pp.38〜46，1983.10

3）小久保彰，半貫敏夫，秋山宏：鋼構造梁降伏型魚骨多層骨組の損傷分布 則，日本建築学会構造系論文集，第 614 号，pp.29３4，2007.4.

4）寺本隆幸,北村春幸：銅構造ラーメン架構の強震時弾塑性応答性状一柱 はり耐力比と高さ方向耐力分布が応答に与える影響一, 日本建築学会構 造系論文集 第 363 号，pp.57〜66，1986.5.

5）小川厚治,加村久哉,井上一朗 : 鋼構造ラーメン骨組の魚骨形地震応答解析 モデル，日本建築学会構造系論文集 第 521 号，pp.119～126，1999.7.

6）吳相勲，山田哲,秋山宏 : 梁柱耐力比及び岡性比を考慮した梁降伏型鋼構 造多層骨組の損傷分布則, 日本建築学会構造系論文集 第 506 号, pp.171 $\sim 177,1998.4$

7）社団法人 鋼材俱楽部: 中低層鉄骨建物の耐震設計法, 技報堂出版, pp.471 $\sim 484,1983$

8）山田哲,秋山宏 : 梁柱耐力比及び岡性比を考慮した梁降伏型鋼構造多層骨 組の損傷分布則, 日本建築学会構造系論文集 第 506 号, pp.171 177, 1998.4 .

（2007年11月 9 日原稿受理，2008年 5 月 14 日採用決定）

最下部節点部材の損傷予測 